\title{
SEED MORPHOLOGY OF THE NATIVE SPECIES OF THE GENUS RIBES L. PART 2. THE CHARACTERISTICS OF INDIVIDUAL SPECIES
}

\author{
DOROTA WROŃSKA-PILAREK \\ Department of Forest Botany, Agricultural University \\ Wojska Polskiego 71d, 60-625 Poznań, Poland
}

(Received: April 25, 2001. Accepted: October 15, 2001)

\begin{abstract}
In this work the results of studies on the seed morphology of 6 native species of the genus Ribes L.: R. uvacrispa L., $R$. nigıum L., $R$. alpinum L., $R$. petraeum Wulfen, $R$. rubrum L. and $R$. spicatum Robson are presented. The diagnostic features of the investigated seeds are: colour and sarcotesta structure, aril size, seed coverage by arils, seed outline and the length to width ratio. The complex of these features allows to differentiate such species, as $R$. uva-crispa, $R$. nigrum and $R$. alpinum. The other species: $R$. petraeum, $R$. rubrum and $R$. spicatum can not be seperated, on the basis of the seed. Within the seeds devoid of outer parenchymal layers of exotesta only the seeds of R. uva-crispa and R. nigrum can be seperated. Then the seeds of other species look the same. Two keys to determine the seeds of the investigated species, based on the fruit features, fresh seeds and "cleaned" seeds form the recapitulation of the work.
\end{abstract}

KEY WORDS: Grossulariaceae, Ribes, seed morphology, fruit morphology, SEM, LM.

\section{INTRODUCTION}

The article contains the description of the seed morphology of 6 native species of the genus Ribes: $R$. uva-crispa L., $R$. nigrum L., R. alpinum L., $R$. petraeum Wulfen, $R$. rubrum L. and $R$. spicatum Robson. For the first time the investigations on the seed structure of currants were based on the seeds without external, parenchymal exotesta layers. That is why my results are different from results of Brouwer and Stählin (1955), Schermann (1967) or Anderberg (1994), who took up this problem. The general characteristics of seed structure of the native species of Ribes and the data referring to the investigation methods were published in the first part of this article (Wrońska-Pilarek, 2001).

\section{DETAILED CHARACTERISTICS OF THE FRUIT AND SEED STRUCTURE OF THE POLISH NATIVE SPECIES OF RIBES L.}

RIBES UVA-CRISPA L. (subgen. Grossularia) - Figs 1-4 Fruit structure: berry elipsoidal in shape, grey-yellow (RHS 160a, $b^{1}$ ). Sappy, sour parenchyma mostly develop from well marked pericarp, in a slight degree from arils.

1 The colours of fruits and seeds were marked according to the colour scale of the Royal Horticultural Society - RHS, worked out by Synge (1966). The number of colour and a letter mark of the tinge are given in the characteristics of particular species.
Parenchyma yellow-white (RHS 158c, d) or orange-white (RHS 159d).

Fresh seed structure:

Sarcotesta: consisting of very large cells. Very thick, tremellose, usually colourless and transparent

Arils: partly cover the seed. Two types: funicular arils white, shapless outgrowths, with the visible vascular bundles along the raphe. The other arils of unknown origin-little, hood-like or saucer-like, yellow-orange or orange outgrowths, only covering the zone of hilum (RHS 23a, b, $24 \mathrm{a}, 25 \mathrm{~b}$ ). Arils with dense consistency, not juicy, sweet in taste.

Raphe: soaken in transparent sarcotesta, well visible. It ranges along the lateral or ventral edge of seed from the hilum towards the micropyle, grown to the seed surface. Cylindrical, white or cream-white.

The "cleaned seed" size (Table 1):

medium; length (2.1-)2.5-2.8(-3.5) mm, width (0.9-)1.2$-1.5(-1.9) \mathrm{mm}$, thickness $(0.75-) 0.8-1.0(-1.3) \mathrm{mm}$, length/ /width ratio: (1.4-)2.0(-2.8).

The "cleaned seed" structure:

Outline: elliptical, rarely broadly elliptical, ovate or eliptically oblong

Apex: acute, pointed, sometimes obtuse.

Base: usually obtuse, rounded, truncate, rarely acute or retuse

Hilum: elliptical, ovate, sometimes triangular.

Micropyle trace: most often elliptical, ovate or triangular. 

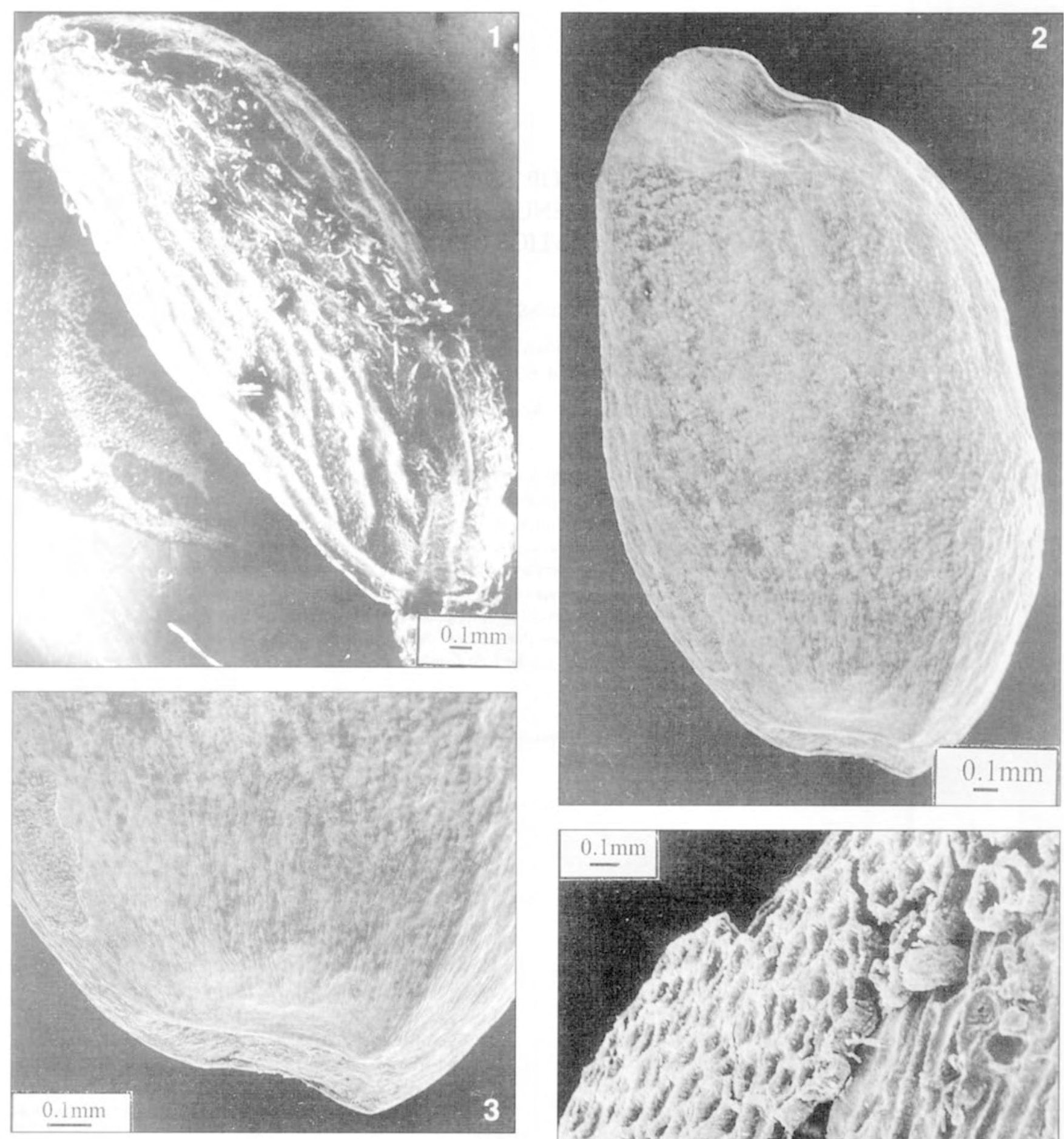

Figs 1-4. Rihes ma-crispal.

Fig. 1. (SEM) - The seed covered with the outer, dried up layers Fig. 2. (SEM) - The seed without sarcotesta: broadly elliptical Fit 3 (SEM) - The elliptical, crater-like hilum $(\times 60)$.

Fig. 4. (SEM) - The close up of seed surface; outside reticulate sclerotesta. elongated cells of cellulosae-pectinous layer below it

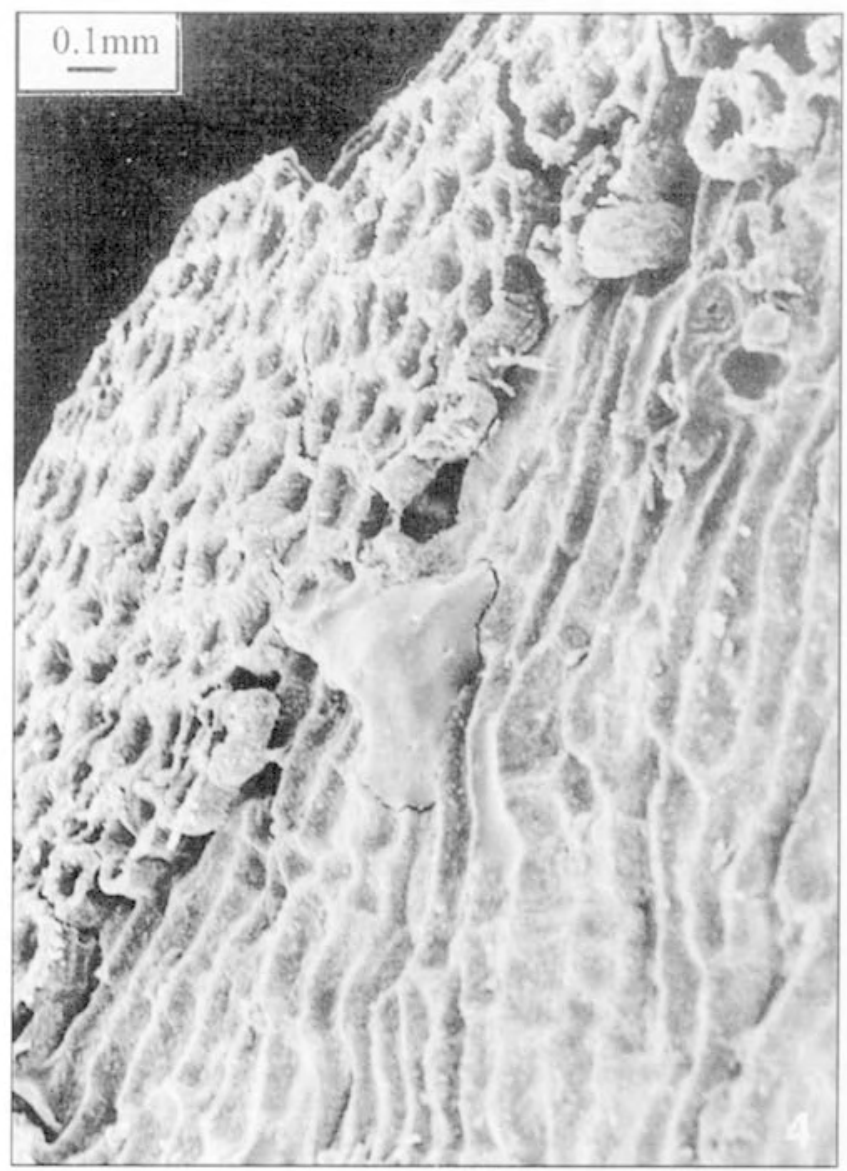


Symmetry: dorso-ventral, seeds 2-3- or multiangular. Sclerotesta: To the naked eye its surface seems to be smooth, under magnification the microsculpture is reticulate. It is mat or with slight polish, grey-orange (RHS 163d, 164a, b, c 165a, b, c, 166d) or grey-brown (RHS 199b).

Microsculpture of cellulosae-pectinous layer: \pm distinctly striate. Most striae runs along the seed rectilinearly or undulately, partly perpendicularly to the seed axis.

Diagnostic features: The fruits ellipsoidal, grey-yellow. Pericarp thick. Parenchyma yellow-white, orange-white, juicy. Sarcotesta of fresh seeds very thick, tremellose, usually colourless and transparent. Two types of arils, partly covering the seed: one shapeless, white, running along the raphe, second small, yellow-orange or orange, only covering the zone of hilum. Arils and parenchyma different in coulor, taste and consistency. Seed elongate, usually elliptical, rarely broadly elliptical, ovate or elliptically oblong. Average length to width ratio 2.0.

Discussion: Pohl (1923) describes the anatomical structure of parenchyma, sarcotesta and arils in the same way as I do. However, he distinguishes one type of transparent funicular arils, running along the funicle. Rauh (1941) presents a fruit drawing with the little aril placed only above hilum. Kraus (1949) observes large, juicy cells of outer integument of seed-coat and of hood-like arils, surrounding the seed of Ribes uva-crispa. Komar (1966) in his description of the pericarp of this species makes mention of "small arilloids, developing along the raphe", which have no significance in the pericarp structure. Both Brouwer's and Stählin's (1955), Schermann's (1967) and Anderberg's (1994) data, concerning the dimension, shape, colour and sculpture of seed surface differ from the results, presented in this work. These differences result from the fact that above-mentioned authors characterize seeds of goosberry covered with the dry sarcotesta cells and parenchymal layer. Samples examined: POLAND. ZACHODNIO-POMORSKIE PROV. - Stargard Szczeciński, allotment garden, 05.08.1993, leg. Wrońska-Pilarek; POMORSKIE PROV. - Sulẹczyno, on the elevation near the lake in Sulẹczyn, 08.08.1994, leg. Wrońska-Pilarek; BYDGOSKIE PROV. - Mogilno, house garden, 27.06.1993, leg. Morkowski; WIELKOPOLSKIE PROV. - Bolechowo, beside the stream near Bolechowskie lake, 14.07.1993, leg. WrońskaPilarek; - Poznań, house garden, 15.07.1993, leg. Maciejewska; Wielkopolski National Park, near the TB preventorium, 20.08.1994, leg. Maliński; DOLNOŚLĄSKIE PROV. - Krowiarki, near Romanowo village, 520 m, 14.07.1993, leg. Boratyński; Sokołowsko, Kamienne Mts, margin of mixed mountain forest, 15.08.1993, leg. Filipiak; LUBELSKIE PROV. - Kazimierz Dolny, oak-beam forest, on the slope near the PTTK shelter-home, 22.07.1993, leg. Wrońska-Pilarek.

\section{RIBES NIGRUM L. (subgen. Coreosma) - Figs 5-7}

Fruit structure: berry spherical, black, covered with the glands, looking like light dots (RHS 202a). Parenchyma mostly formed by the arils, so it is not sappy but thick and slightly sticky; usually dark-red (RHS 45c, 46b, c, 47a, b, $53 \mathrm{~b}, \mathrm{c}$ ).

\section{Fresh seed structure:}

Sarcotesta: tremellose, transparent, coloured \pm as parenchyma

Arils: cover the whole seed. The funicle arils very well developed, spread outside the area of testa. They run along the raphe and attain the greatest sizes in the area of micropyle trace and below this zones. They are usually shapeless with parted or lobed margins, colourless or take the dark-red colour of sarcotesta

Raphe: partly marginally grown to sclerotesta cells. It ranges from hilum toward the micropyle trace. Cylindrical, cream-white

The "cleaned seed" size (Table 1):

small; length (1.5-)1.7-2.0(-2,4) mm, width (0,8-)1.0-1.2 $(-1.4) \mathrm{mm}$, thickness (0.2-)0.7-09(-1:1) mm,

length/width ratio: (1.3-) $1.8(-2.7)$.

\section{The "cleaned seed" structure:}

Outline: elliptical, rarely broadly elliptical, ovate-lanceolate or ovate

Apex: acute, pointed or retuse.

Base: roundish, truncate, acute or retuse.

Hilum: elliptical or inversely triangular.

Micropyle trace: most often elliptical, rarely obovate or rhomboidal.

Symmetry: dorso-ventral, seeds 2-3-angular.

Sclerotesta: microsculpture reticulate. Grey-orange (RHS $162 \mathrm{a}, 164 \mathrm{a}, \mathrm{b}, \mathrm{c}, 165 \mathrm{~b}$ ); slightly polish or mat.

Microsculpture of cellulosae-pectinous layer: striate. Formed by erect or undulate striae, running along the seed, rarely perpendicularly to seed axis.

Diagnostic features: Black berry. Parenchyma dark-red, not sappy, thick, lightly sticky. Sarcotesta of fresh seeds of medium thickness, tremellose, transparent, coloured similarly as parenchyma. Arils fully developed, covering the whole seed. Seeds small, the smallest whithin investigated species, elongate, usually elliptical in outline, rarely broadly elliptical, ovate-lanceolate or ovate. Most often length to width ratio 1.8 .

Discussion: Brouwer's and Stählin's (1955), Schermann's (1967) and Anderberg's (1994) data concerning the dimensions, sculpture, colour and polish of seeds of Ribes nigrum are diffrent from my results, because these authors described the seeds covered with dry cells of sarcotesta and of parenchymal layer. Komar (1966) states the pericarp of $R$. nigrum to be very thin. According to him the main mass of fruit parenchyma is formed by arils, which as the berry ripens become larger and larger.

Samples examined: POLAND. POMORSKIE PROV. - Gać, Słowiński National Park, "Olszyna" reserve, 15.06.1993, leg. Filinger; ZACHODNIO-POMORSKIE PROV. - Stargard Szczeciński, allotment garden, 05.08.1993, leg. Wrońska-Pilarek; Warnowo, alder carr beside the Warnowo lake, 04.08.1993, leg. Wrońska-Pilarek; BYDGOSKIE PROV. - Mogilno, house garden, 27.06.1993, leg. Morkowski; WIELKOPOLSKIE PROV. Owińska over the Warta river, alder carr, 14.07.1993, leg. Wrońska-Pilarek; DOLNOŚLĄSKIE PROV. - Wrzosy, marshy meadow in the valley of the Juszki river, 13.07.1993, leg. Bobrowicz; ŚLĄSKIE PROV. - Lipnik forestry, slope of Szyndzielnia Mt., 20.07.1993, leg. Gancarczyk; LUBELSKIE PROV. - Zwierzyniec, Roztocze National Park, alder carr beside the Świerszcz river, near the Echo pond, 19.07.1993, leg. Wrońska-Pilarek.

RIBES ALPINUM L. (subgen. Berisia) - Figs 8-11

Fruit structure: berry red (RHS 42c, 45c, 46c, 47b). Pericarp very thin, mostly determined by the plancetar arils, in a less degree by the funicular arils. It has thick, sticky consistency. Pericarp, orange (RHS 24c, 26c) or orange-red (RHS 32c, 33c), lightly sweet and insipid. 



Figs 5-7. Ribes nigrum L.

Fig. 5. (SEM) - The seed covered with the outer, dried up layers of sarcotesta $(\times 55)$.

Fig. 6. (SEM) - The seed without sarcotesta: broadly elliptical: the base and the apex broadly acute $(\times 55)$.

Fig. 7. (SEM) - The seed round; the base and the apex truncate $(\times 45)$.

\section{Fresh seed structure:}

Sarcotesta: transparent, coloured just as parenchyma. Usually parenchymal cell-walls of sarcotesta distinctly marked, owing to their significant thickness and darkbrown colour. They form reticule, also \pm visible after sar- cotesta drying. The significance mean of this feature requires further investigations

Arils: cover the whole seed. Two types, the plancetar arils very well developed, outgrowing the sarcotesta and funicular arils, smaller, placed in the area of sarcotesta, usually 

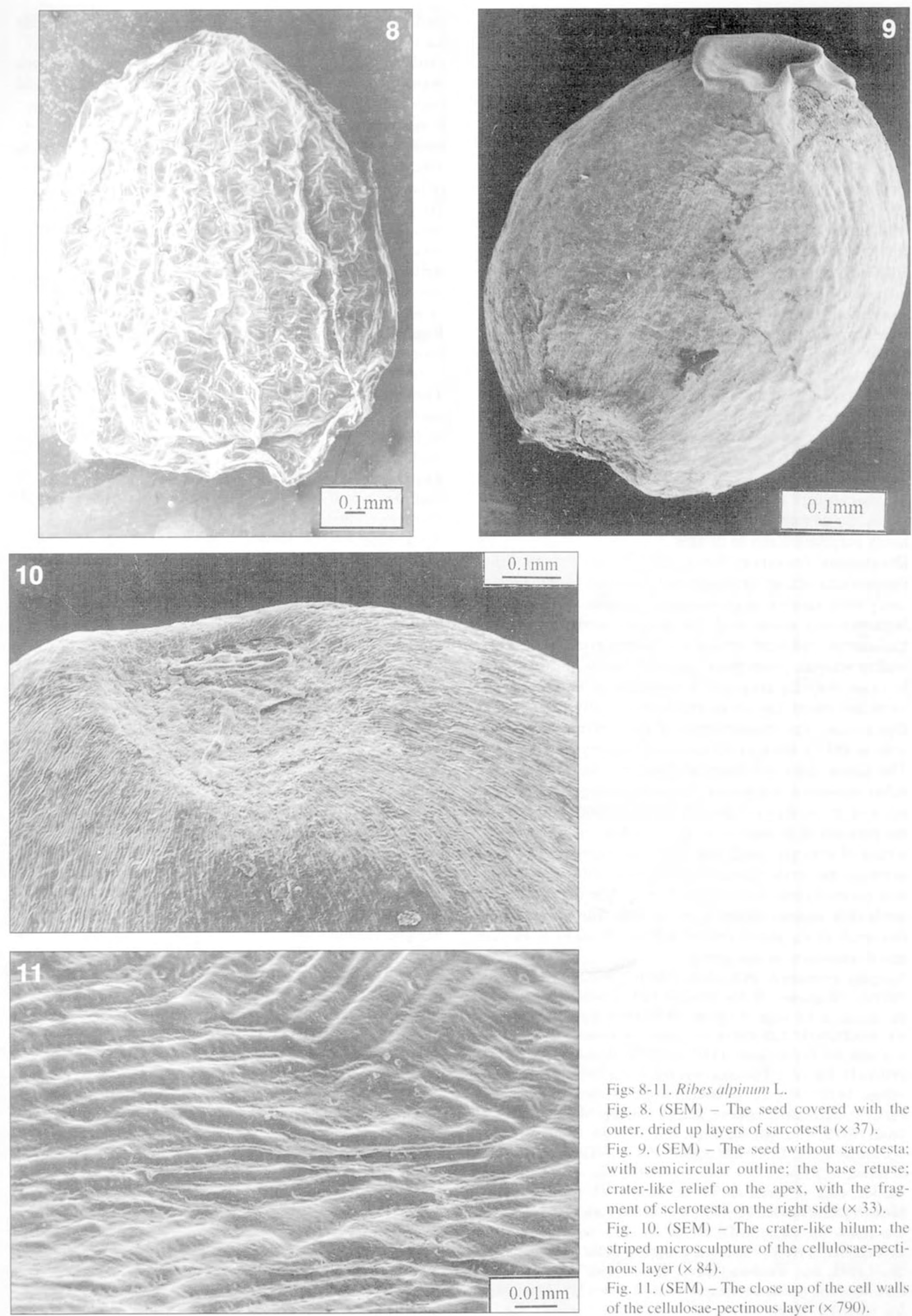

Figs 8-11. Ribes alpinum L.

Fig. 8. (SEM) - The seed covered with the outer, dried up layers of sarcotesta $(\times 37)$.

Fig. 9. (SEM) - The seed without sarcotesta: with semicircular outline: the base retuse: crater-like relief on the apex, with the fragment of sclerotesta on the right side $(\times 33)$. Fig. 10. (SEM) - The crater-like hilum; the striped microsculpture of the cellulosae-pectinous layer $(\times 84)$.

Fig. 11. (SEM) - The close up of the cell walls of the cellulosae-pectinous layer $(\times 790)$. 
over the hilum. The aril cells are so close together inside a fruit, that the parenchyma looks like homogeneous mass, with soaken seeds. That is why the determination of aril shapes is difficult

Raphe: partly, marginally grown to sclerotesta cells. It ranges from the hilum toward the micropyle trace. Cylindrical, cream-white

The "cleaned seed" size (Table 1): medium; length (1.8-)2.0-2.3(-2.6) mm, width (1.3-)1.5$-1.7(-2.2) \mathrm{mm}$, thickness (0.8-)1.0-1.3(-1.5) mm, length/ /width ratio: (1.0-) 1.3-1.5(-2.0)

The "cleaned seed" structure:

Outline: most often broadly ovate, broadly elliptical or roundish but also ovate and round

Apex: obtuse, roundish, retuse, rarely acute or pointed.

Base: roundish, truncate or retuse

Hilum: elliptical, ovate or triangular.

Micropyle trace: elliptical, ovate or triangular.

Symmetry: dorso-ventral, seeds slightly 2-3-angular.

Sclerotesta: microsculpture reticulate. The tinges range from grey-orange (RHS 163c, 165b, 166c, 167b, c, d, 168c, 171c, 177a, b, d), grey (RHS 201a) to brown (RHS 200a); lightly polish or mat.

Microsculpture of cellulosae-pectinous layer: shallowly striate. Striae run rectilinearly or undulately along the seed, rarely perpendicularly to its axis

Diagnostic features: berry red. Pericarp very thin. Parenchyma orange or orange-red, thick, of sticky consistency (not sappy), slightly sweet, insipid. It looks like homogeneous mass, with the soaken seeds. Sarcotesta transparent, coloured similarly as parenchyma. Arils very well developed, cover the whole seed. Seeds mostly broadly ovate, broadly elliptical or roundish in outline, rarely ovate and round. Length to width ratio usually 1.3-1.5.

Discussion: The characteristic of parenchyma as well as arils in Pohl's work (1923) is similar to my observations. The author does not describe, however, the sarcotesta of Ribes alpinum and does not show morphological characteristics of the seed of the species. Komar (1966) only notices the pericarp of $R$. alpinus to be very thin and mainly consisting of strongly developed arils. Anderberg (1994) characterizes the seeds covered with the dry cells of sarcotesta and parenchymal layer. That is why her description of seeds of $R$. alpinus differs from my data. The author classifies seeds of the alpine currant with the seeds of $R$. rubrum and $R$. spicatum, as one group.

Samples examined: POLAND. ZACHODNIO-POMORSKIE PROV. - Warnowo, Wolin National Park, marshy meadow near the stream, at the edge of village, 04.08.1993, leg. Wrońska-Pilarek; MAZOWIECKIE PROV. - Trębaczew Reserve, pine-oak forest with the Polish larch, 13.07.1993, leg. Maliński; WIELKOPOLSKIE PROV. - Owińska over the Warta river, the way from village, 14.07.1993, leg. Wrońska-Pilarek; Wielkopolski National Park, "Pod Dziadem" reserve, 20.08.1994, leg. Maliński; LUBUSKIE PROV. - Rzepin, the forest near the town, 08.08.1993, leg. Wrońska-Pilarek; DOLNOŚLĄSKIE PROV. - Grodzieniec, edge of forest, ca 300 m, 27.09.1993, leg. Boratyński; - Kletno, Śnieżnik Mt., edge of forest ca $500 \mathrm{~m}, 22.09 .1993$, leg. Boratyński; MALOPOLSKIE PROV. - Ojców National Park, slope of mountain below the castle in Ojców, 07.09.1993, leg. Danielewicz; LUBELSKIE PROV. - Zamość, hedgerow in the municipal park, 20.07.1993, leg. Wrońska-Pilarek; Zwierzyniec - Roztoczański Park National, beside the route towards Bukowa Mt., 19.07.1993, leg. Wrońska-Pilarek.
RIBES PETRAEUM WULFEN (subgen. Ribes) - Figs 12-15

Fruit structure: berry red (RHS 45a, 46a). Parenchyma mainly formed by pericarp, tremellose, sappy, of red colour (RHS 45b, 46b), very sour in taste.

Fresh seed structure:

Sarcotesta: red, brighter than parenchyma (RHS 42b, c, $43 \mathrm{~b}, 44 \mathrm{c})$. The parenchymal cell-walls of sarcotesta strongly thickened, darkly coloured and so distinctly marked. They form characteristic reticule (compare Ribes alpinum), also well visible after sarcotesta drying. The significance mean of this feature requires further investigations

Arils: strongly reduced. The funicular arils look like small, convex outgrowths, placed over hilum. Arils yellow-white or white (rarely red), with slightly lobed margin

Raphe: partly, marginally grown to the sclerotesta. It ranges from the hilum toward the micropyle trace. Cylindrical, cream-white

The "cleaned seed" size (Table 1):

medium; length (1.9-)2.0-2.3 (-2.6) mm, width (1.3-)1.5$-1.7(-2.2) \mathrm{mm}$, thickness (1.0-)1.2-1.3(-1.7) mm, length/ /width ratio: (1.0-)1.2-1.5(-1.9).

The "cleaned seed" structure:

Outline: broadly ovate, broadly elliptical, ovate or roundly ovate, rarely roundish

Apex: roundish, retuse, rarely acute or pointed.

Base: roundish, truncate, retuse or acute.

Hilum: elliptical, obovate or triangular.

Micropyle trace: elliptical, obovate or triangular.

Symmetry: dorso-ventral, seeds slightly 2-3-angular.

Sclerotesta: to the naked eye seems to be smooth, however under the magnification it occures to be reticulate. Greyorange (RHS 161c, 164c, 165a, b, c, 166c, 168c, d) and grey-yellow (RHS 162a, b), slightly polish or mat.

Microsculpture of cellulosae-pectinous layer: deeply striate. Striae deep, well visible, running along the seed, rarely perpendicularly to seed axis or slightly undulately

Diagnostic features: berry red. Parenchyma red, very sour in taste, tremellose, sappy. Arils reduced to little outgrowths placed over the hilum. Seeds broadly ovate, broadly elliptical, ovate, roundly ovate, rarely roundish. Usually length to width ratio 1. 2-1.5.

Discussion: Any cited above elaborations do not include morphological characteristics of seeds of this species.

Samples examined: POLAND. DOLNOŚLĄSKIE PROV. - Maty Staw, Karkonosze National Park, $200 \mathrm{~m}$ from the pond and beside the blue route, $c a 1180 \mathrm{~m}, 21.08 .1993$, leg. Maciejewska and Maliński; MALOPOLSKA PROV. - Babia Góra National Park, at left from the track toward Brona; squad 23b, ca $1240 \mathrm{~m}$, 25.09.1993, leg. Rzepka; - Tatra National Park, the Kościeliska dale, beside the Kościeliski stream, 12.06.1993, leg. Wrońska-Pilarek and Maciejewska, Mały Giewont Mt., 1728 m., 11.06.1993, leg. Wrońska-Pilarek and Maciejewska; Miedziane Mt., the thicket of the dwarf mountain pine, ca $2000 \mathrm{~m} ., 22.08 .1992$, leg. Danielewicz.

RIBES RUBRUM L. (subgen. Ribes) - Figs 16-19

Fruit structure: berry red (RHS 42a, 43c, 45a, b, c, 46a, b, c, 50a). Parenchyma mainly formed by the pericarp, tremellose, sappy, sour in taste, of red colour (RHS 45c, d, 46d).

Fresh seed structure:

Sarcotesta: transparent, of colour \pm as parenchyma 

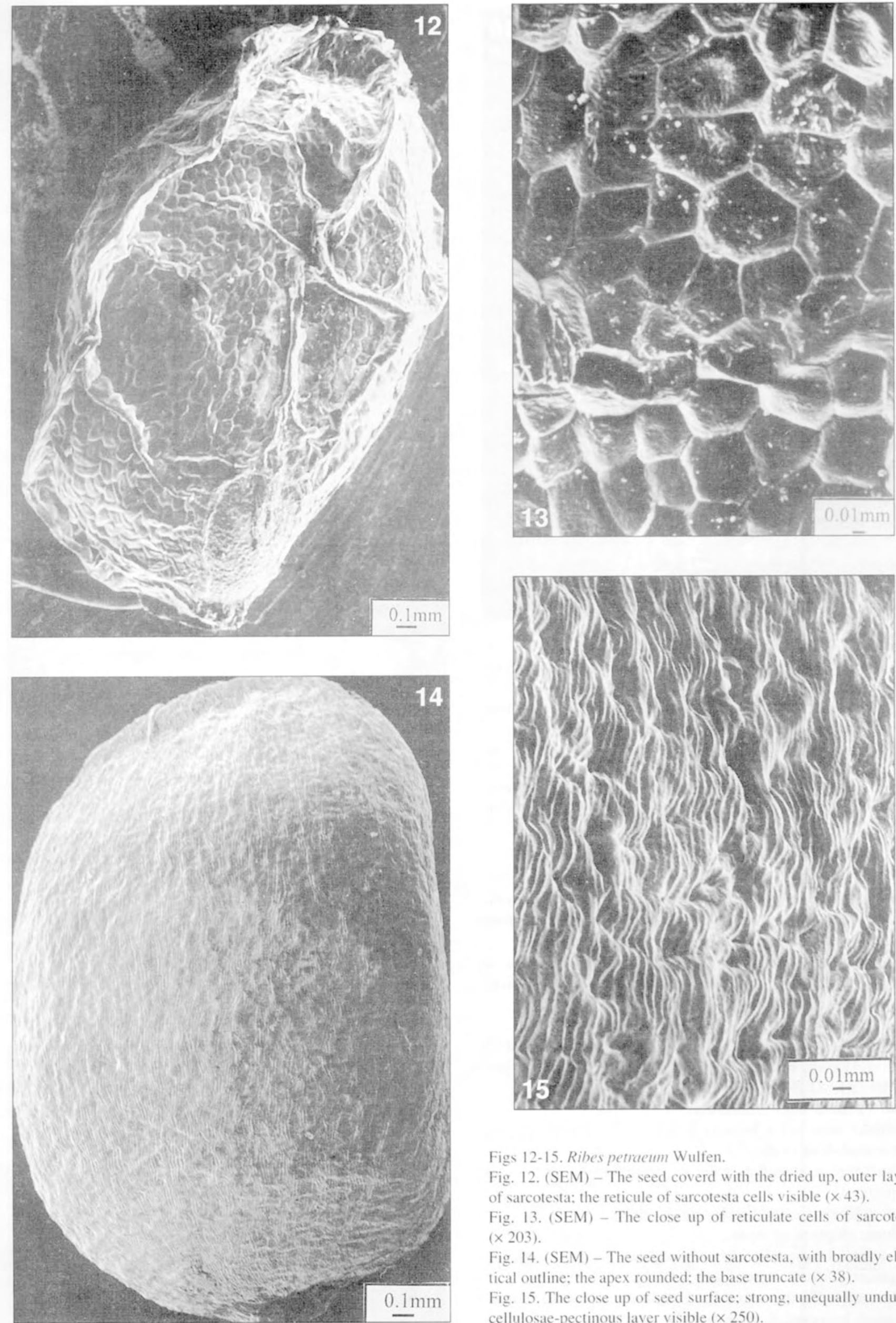

Figs 12-15. Ribes petraeum Wulfen.

Fig. 12. (SEM) - The seed coverd with the dried up, outer layer of sarcotesta: the reticule of sarcotesta cells visible $(\times 43)$.

Fig. 13. (SEM) - The close up of reticulate cells of sarcotesta Fig. 14. (SEM) - The seed without sarcotesta, with broadly elliptical outline; the apex rounded; the base truncate $(\times 38)$.

Fig. 15. The close up of seed surface; strong, unequally undulate cellulosae-pectinous layer visible $(\times 250)$. 


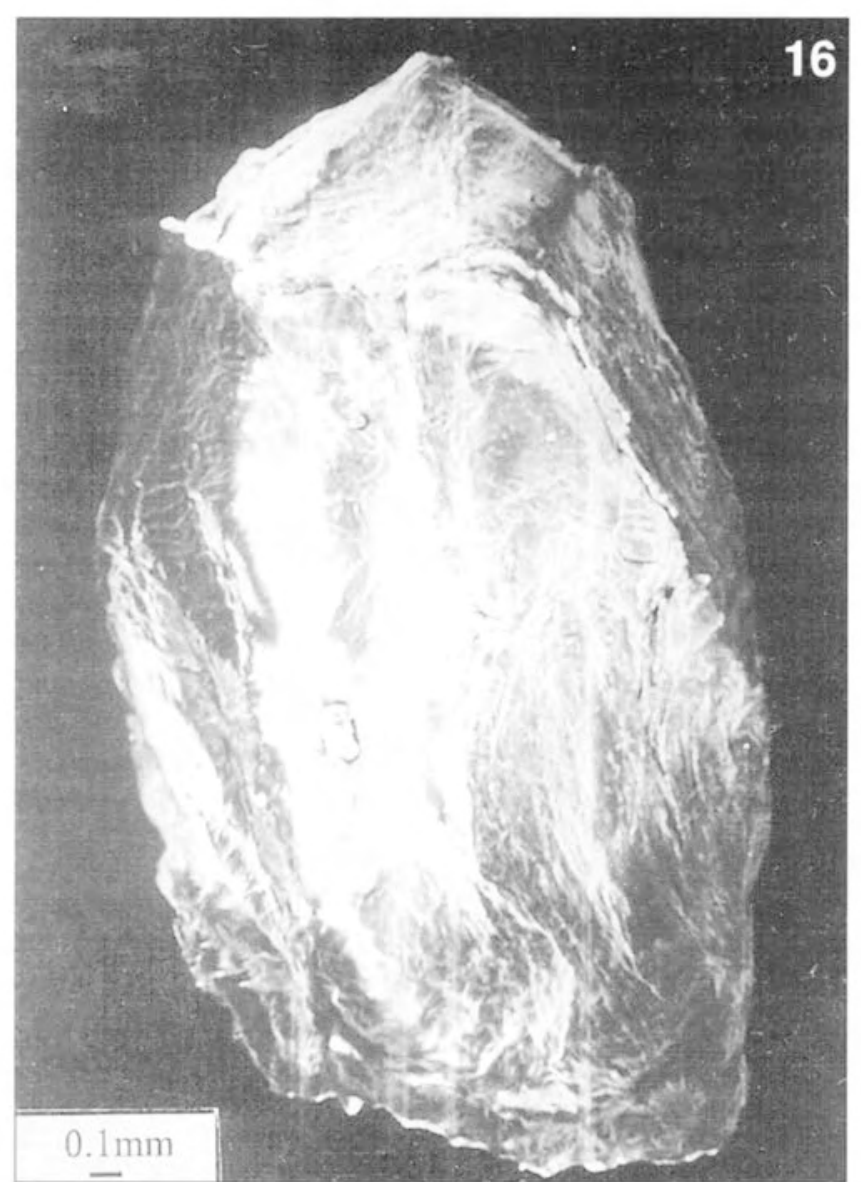

Figs 16-19. Ribes nubrum L.

Fig. 16. (SEM) - The seed covered with the outer, dried up layers of sarcotesta $(\times 30)$.

Fig. 17. (SEM) - The seed without sarcotesta, with broadly elliptical outline: the base retuse: the apex rounded $(\times 26)$.

Fig. 18. (SEM) - The seed without sarcotesta, with roundly ovate outline, the base and the apex truncate $(\times 26)$.

Fig. 19. (SEM) - The close up of the seed surface, the undulate striae of cellulosae-pectinous layer, running along the seed visible $(\times 120)$.

Arils: strongly reduced. The funicular arils look like small, yellow-white, convex outgrowths, with shallow-lobed margin. placed near the base of seed. over the hilum

Raphe: partly, marginally growing to the sclerotesta. It ranges from the hilum toward the micropyle trace. Cylindrical, cream-white

The "cleaned seed" size (Table 1):

medium: length (1.7-)2.2-2.8(-3.2) mm, width (1.4-)1.5$-2.0(-2.3) \mathrm{mm}$, thickness $(0.8-) 1.0-1.4(-1.7) \mathrm{mm}$, length/ /width ratio: (1.0-) 1.2-1.5(-2.1).

\section{The "cleaned seed" structure:}

Outline: most often broadly ovate, rarely broadly elliptical, roundish or ovate

Apex: obtuse, roundish, truncate, sometimes acute, retuse or pointed.

Base: obtuse, roundish, truncate or retuse.

Hilum: elliptical or ovate.

Micropyle trace: elliptical or triangular.

Symmetry: dorso-ventral, seeds slightly 2-3-angular.

Sclerotesta: To the naked eye is smooth, under the magnification, however, it appears to be reticulate. Slightly pol-
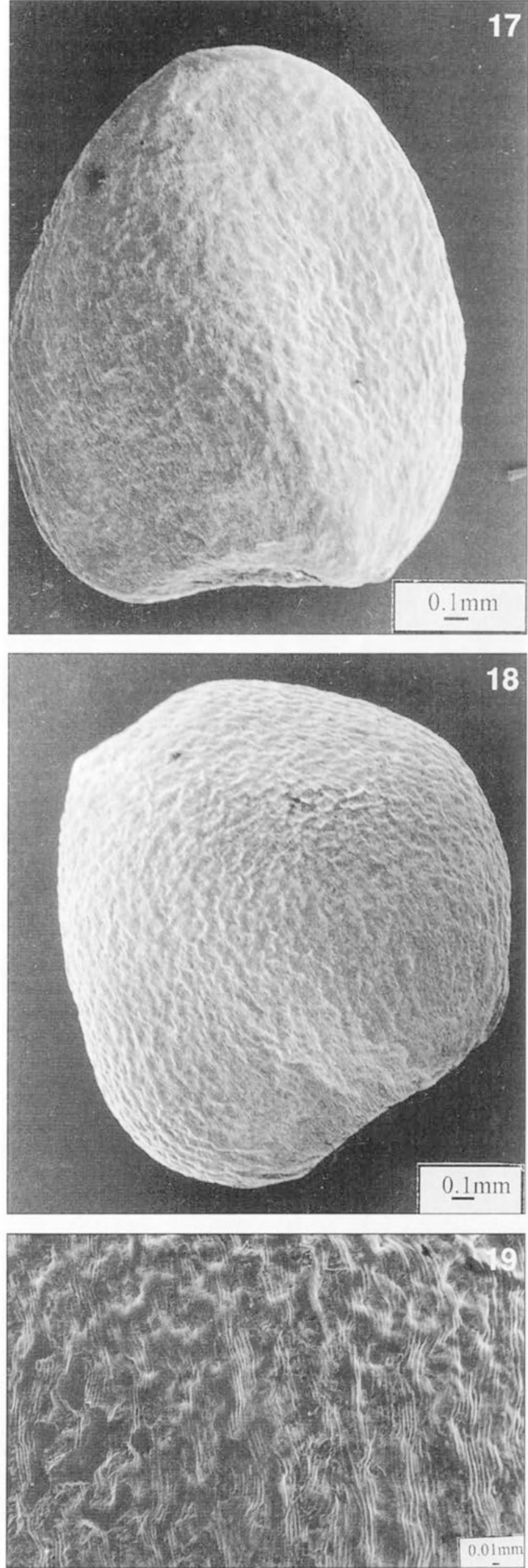
ish or mat, with grey-orange (RHS 164a, b, 165a, b, c, $166 \mathrm{a}, \mathrm{b}, \mathrm{c}, 175 \mathrm{a}$ ) or brown (RHS 200a, b, c, d) tinges.

Microsculpture of cellulosae-pectinous layer: striate. Striae rectilinear or undulate, run along the seed, rarely perpendicularly to its axis

Diagnostic features: berry red. Parenchyma red, sour, tremellose, sappy. Seed sarcotesta transparent, about the colour less or more similar to the parenchyma colour. Arils reduced to little outgrowths placed over hilum. Seeds mostly broadly ovate, rarely broadly elliptical, roundish or ovate, length to width ratio 1.2-1.5.

Discussion: Pohl (1923) states that the parenchyma of Ribes rubrum is formed almost exclusively by pericarp and to a slight degree by funicle. According to this author, arils at $R$. rubrum practically do not occur, because the funicle only in minimal part evolves into aril here. In 1926 Netolitzky published a schematic drawing of cross-section of seed of $R$. rubrum. In principle my investigations confirm his observations, concerning the arrangement and structure of each seed-coat layers. Brouwer's and Stählin's (1955), Schermann's (1967) and Anderberg's (1994) data referring to the dimensions, sculpture, colour and polish of seeds of $R$. rubrum more or less differ from my results. That is because the cited authors describe the seeds covered with parenchymal exotesta layers. Komar (1966) considers the arils $R$. vulgare Lam. (=R. rubrum L.) and of $R$. pubescens Hedl. ( $=R$. spicatum Robson) to be poorly developed. So they practically have no significance in the parenchyma structure of the described species. In Corner's (1976) opinion the arils at $R$. rubıum are reduced to protruding, slightly crenate, fleshy placenta, placed near the seed base. Anderberg (1994) classifies seeds of R. rubrum with the seeds of $R$. alpinum and of $R$. spicatum, as one group. Samples examined: POLAND. POMORSKIE PROV. - Sulęczyno, marshy meadow beside the lake in Sulẹczyno, 08.08.1994, leg. Wrońska-Pilarek; ZACHODNIOPOMORSKIE PROV. Stargard Szczeciński, allotment garden, 15.07.1994, leg. Wrońska-Pilarek; KUJAWSKO-POMORSKIE PROV. - Potulice forestry, the oak-beam forest, between the sections 141 and 144 , 30.04.1993, leg. Wrońska-Pilarek and Maciejewska; WIELKOPOLSKIE PROV. - Bolechowo, beside the stream near the Bolechowskie lake, 14.07.1993, leg. Wrońska-Pilarek; - Poznań, house garden, 15.07.1993, leg. Maciejewska; - Włodzimirów, marshy meadow beside the pond near the forester's lodge, 28.07.1994, leg. Wrońska-Pilarek and Maliński; DOLNOŚLĄSKIE PROV. - Sokołowsko, house garden, 08.08.1994, leg. Filipiak; LUBELSKIE PROV. - Kazimierz Dolny, beside the castle ruins, 22.07.1993, leg. Wrońska-Pilarek.

RIBES SPICATUM ROBSON (syn. Ribes schlechtendalii Lange) (subgen. Ribes) - Figs 20-23

The morphological features of parenchyma, sarcotesta, arils and raphe at Ribes spicatum are the same as at above described $R$ rubrum. Seeds of $R$. spicatum and $R$. rubrum are very difficult to distinguish from each other (compare with $R$. rubrum Fig. 5). In my investigations $R$. spicatum and $R$. rubrum insignificantly differed in seed size and in seed shape.

Besides, the seed apex of $R$. spicatum is obtuse, roundish, truncate, acute or retuse, while the base is obtuse, roundish, truncate or retuse. The hilum and micropyle trace are elliptical, ovate and triangular. The sclerotesta of $R$. spicatum has grey-orange (RHS 163d, 164a, b, c, 165a, b, 166a, b, 175a, 177a) and brown (RHS 200a, b) tinges.
Sclerotesta of $R$. spicatum is reticulate, similarly as at $R$. rubrum. The microsculpture of cellulosae-pectinous layers is formed by rectilinear or undulate striae, running along the seeds rectilinearly or slightly in waves, rarely perpendicularly to seed axis.

Diagnostic features: According to seed structure R. spicatum and $R$. rubrum do not reveal any differences. In relation to the rest of species diagnostic features are the same as at $R$. rubrum.

Discussion: Anderberg (1994) characterizes seeds of Ribes spicatum covered with dry sarcotesta cells and parenchymal layers. That is why her description is not consistent with description given in my work. This author classifies the seeds of $R$. spicatum within one group, with the seeds of $R$. alpinum and $R$. rubrum. Any cited author here does not include any characteristics of the seeds of this species.

Samples examined: POLAND. ZACHODNIO-POMORSKIE PROV. - at the seaside, Pomeranian beech, $c a$ 200-300 $\mathrm{m}$ from Mielno, 07.09.1993, leg. Maciejewska; - Podczele near Kołobrzeg, alder carr, $c a 200 \mathrm{~m}$ from the road toward Koszalin, 04.09.1993, leg. Adamczak; - Warnowo, Woliński National Park, marshy meadow beside the Warnowo lake, 04.07.1993, leg. Wrońska-Pilarek; POMORSKIE PROV. - Gać, Słowiński National Park, "Olszyna" reserve, 15.06.1993, leg. Filinger; KUJAWSKO-POMORSKIE Prov. - Mogilno, house garden, 27.06.1993, leg. Morkowski; - Potulice forestry, section 144, 30.07.1993, leg. Wrońska-Pilarek and Maciejewska; WIELKOPOLSKIE PROV.Owińska over the Warta river, marshy meadow, 14.07.1993, leg. Wronska-Pilarek; - near the Słomowo village, alder carr, 14.07.1994, leg. Wrońska-Pilarek; 9. DOLNOŚLĄSKIE PROV. - Wrzosy, 8 km NE from Wołowo, marshy meadow, 13.07.1993, leg. Bobrowicz.

\section{KEY BASED ON THE CHARACTERS OF FRUITS AND FRESH SEEDS}

1A. Fruit ellipsoidal or ovate, grey-yellow. Parenchyma of ripe fruit yellow-white or orange-white. Sarcotesta transparent. Two types of arils: hood-like, yelloworange or orange, placed above hilum and shapeless, white, placed along raphe

\section{R. uva-crispa L.}

1B. Fruit spherical, black or red. Parenchyma of ripe fruit orange, orange-red, or red. Sarcotesta \pm coloured similarly as parenchyma

2A. Fruit black, covered with glands, looking like light dots. Parenchyma of ripe fruits usually dark-red. Arils very well developed, covering the whole seed

R. nigrum L.

2B. Fruit red, without glands

3A. Fruit insipid, weakly sappy. Parenchyma of ripe fruit orange- or orange-red. Arils very well developed, covering the whole seed

R. alpinum $\mathrm{L}$.

3B. Fruit sour or very sour, sappy. Parenchyma of ripe fruit red. Arils reduced

R. petraeum Wulfen,

R. rubrum L., R. spicatum Robson 



Figs 20-23. Ribes spicatum Robson

Fig. 20. (SEM) - The seed covered with the outer, dried up layers of sarcotesta $(\times 36)$.

Fig. 21. (SEM) - The seed without sarcotesta. with elliptical outline; the base truncate; the apex rounded $(\times 30)$.

Fig. 22. (SEM) - The zone of micropyle trace; reticulate sclerotesta and elongated. narrow cells of cellulosae-pectinous layer visible $(\times 60)$.

Fig. 23. (SEM) - The zone of hilum; the striae of cellulosae-pectinous layer and fragments of sclerotesta visible $(\times 70)$. 
TABLE 1. Minimum (MIN), maximum (MAX), arithmetic means (x), standard deviation (SD) and coefficient of variability (V) of the general sample of the native species of the genus Ribes $\mathrm{L}$. A - length, B - width, $\mathrm{C}$ - thickness, D - length/width ratio, 1 - R. uva-crispa, $2-R$. nigrum, $3-R$. alpinum, $4-R$. petraeum, $5-R$. rubrum, $6-R$. spicatum.

\begin{tabular}{|c|c|c|c|c|c|c|}
\hline \multirow[b]{2}{*}{ Feature } & \multirow[b]{2}{*}{ Species } & \multicolumn{5}{|c|}{ Statistical characteristics } \\
\hline & & $\mathrm{MIN}(\mathrm{mm})$ & $\operatorname{MAX}(\mathrm{mm})$ & $X(\mathrm{~mm})$ & $\mathrm{SD}$ & V \\
\hline \multirow[t]{6}{*}{ A } & 1 & 2.10 & 3.50 & 2.77 & 0.29 & 10.47 \\
\hline & 2 & 1.50 & 2.40 & 1.90 & 0.13 & 6.84 \\
\hline & 3 & 1.80 & 2.60 & 2.18 & 0.18 & 8.26 \\
\hline & 4 & 1.90 & 2.70 & 2.22 & 0.16 & 7.21 \\
\hline & 5 & 1.70 & 3.20 & 2.41 & 0.26 & 10.79 \\
\hline & 6 & 1.70 & 2.90 & 2.28 & 0.27 & 11.84 \\
\hline \multirow[t]{6}{*}{ B } & 1 & 0.90 & 1.90 & 1.41 & 0.19 & 13.48 \\
\hline & 2 & 0.80 & 1.40 & 1.06 & 0.12 & 11.32 \\
\hline & 3 & 1.30 & 2.20 & 1.64 & 0.18 & 10.98 \\
\hline & 4 & 1.30 & 2.20 & 1.78 & 0.20 & 11.24 \\
\hline & 5 & 1.40 & 2.30 & 1.80 & 0.20 & 11.11 \\
\hline & 6 & 1.20 & 2.50 & 1.74 & 0.22 & 12.64 \\
\hline \multirow[t]{6}{*}{$\mathrm{C}$} & 1 & 0.80 & 1.30 & 1.01 & 0.15 & 14.85 \\
\hline & 2 & 0.20 & 1.10 & 0.79 & 0.09 & 11.39 \\
\hline & 3 & 0.80 & 1.50 & 1.12 & 0.16 & 14.29 \\
\hline & 4 & 1.00 & 1.70 & 1.29 & 0.15 & 11.63 \\
\hline & 5 & 0.80 & 1.70 & 1.23 & 0.16 & 13.01 \\
\hline & 6 & 0.80 & 1.80 & 1.22 & 0.18 & 14.75 \\
\hline \multirow[t]{6}{*}{$\mathrm{A} / \mathrm{B}$} & 1 & 1.40 & 2.80 & 2.05 & 0.29 & 14.15 \\
\hline & 2 & 1.30 & 2.70 & 1.87 & 0.24 & 12.83 \\
\hline & 3 & 1.00 & 2.00 & 1.41 & 0.20 & 14.18 \\
\hline & 4 & 1.00 & 1.90 & 1.32 & 0.15 & 11.36 \\
\hline & 5 & 1.00 & 2.10 & 1.39 & 0.18 & 12.95 \\
\hline & 6 & 1.00 & 2.00 & 1.37 & 0.17 & 12.41 \\
\hline
\end{tabular}

\section{KEY BASED ON THE CHARACTERS OF "CLEANED SEEDS"}

1A. Seeds broadly ovate, broadly elliptical or roundish. Length to width ratio mostly $1.3-1.4$

$R$. alpinum $\mathrm{L}$., $R$. petraeum Wulfen,

$R$. rubrum L., R. spicatum Robson

1B. Seeds elongated, elliptical or ovate. Length to width ratio mostly 1.8-2.0

2A. Seeds small, (1.5-)1.7-2.0(-2.4) mm long, (0.8-)1.0$1.2(-1.4) \mathrm{mm}$ wide. Length to width ratio mostly 1.8 .. R. nigrum $\mathrm{L}$.

2B. Seeds larger, (2.1-)2.5-2.8(-3.5) mm long, (0.9-)1.2$1.5(-1.9)$ wide. Length to width ratio mostly 2.0 R. uva-crispa L.

\section{RESULTS}

The colour and structure of sarcotesta, aril size and aril coverage of the seed, the seed outline and length to width ratio are the main diagnostic features of the seeds of the investigated species. The complex of these features allows to seperate the seeds of Ribes uva-crispa, $R$. nigrum and $R$. alpinum. The other species $R$. petraeum, $R$. rubrum and $R$. spicatum can not be differerentiated basing on the seeds.

The removal of outer, parenchymal layers of exotesta (that is sarcotesta and parenchymal layer) makes the differentiation of current seeds impossible, with the exception of the seeds of R. uva-crispa and $R$. nigrum. The morphological structure of seeds enables to distinguish the species representing separate subgenera. While, within the species the possibility of its use in diagnostics is rather limited.
The initial investigations showed, that the hardest, permanent tissue of currant seeds is not thin sclerotesta, but the layer placed between the seed-coat and endosperm. It is relatively thick and most likely it protects the endosperm and embryo from damage. Precise anatomical investigations and analysis of chemical composition univocally proved, that it is formed by pectins and cellulose. In this connexion the term "outer cuticle" is mistaken. I propose to name this layer as "cellulosae-pectinous layer". Probably it is mainly formed by nucellus cells of ovule, devoid of protoplast. The cellulosae-pectinous layer has a striate microsculpture, due to the walls of strongly elongated cells. All investigated species have a very similar microsculpture of the cellulosae-pectinous layer. So the differentiation of seeds of particular species basing this feature is impossible. During the analysis of the cellulosaepectinous layer I also examined the endosperm structure. It is formed by elongated, thick-walled, loosely arranged cells. It contains nutrients, such as proteins, fats and starch. For the first time I present scanning microphotographs (SEM) of the cellulosae-pectinous layer and of the endosperm.

\section{ACKNOWLEDGEMENTS}

I would like to thank the following persons for help in research work: the staff of the Institute of Botany of the Vienna University, especially Professor Michael Hesse and Dr. Heidemarie Halbritter, under their care I carried out SEM observations and took microphotographs; Professor Jerzy Wiśniewski and his associates (Agricultural University, Poznań), who offered the laboratory to take LM microphotographs; M.Sc. Magdalena Krzesłowska 
(The Mickiewicz University, Poznań), who carried out the analyse of chemical composition of seeds, Dr. Irmina Maciejewska (Agricultural University, Poznań), who translated this article.

I would like to express my gratitude to Professor Jerzy Zieliński (Institute of Dendrology of the Polish Academy of Sciences, Kórnik), for his critical comments on the manuscript.

\section{LITERATURE CITED}

ANDERBERG A. 1994. Atlas of seeds and small fruits of Northwest-European plant species with morphological descriptions. 4: Resedaceae - Umbelliferae. Risbergs Tryckeri AB. Stockholm

BROUWER W. and STÄHLIN A. 1955. Handbuch der Samenkunde. DLG-Verlags-Gmbh. Frankfurt am Mein

CORNER E.J.H. 1976. Grossulariaceae. In: The seeds of dicotyledones 1, 2: 151, 238-239. Cambridge University Press. Cambridge, London, New York, Melbourne
KOMAR G.A. 1966. Anatomitsheskie issledovnia strojenia i razvitia plodovoj obolotshki niekotorych predstavitielei semeistwa Kruzhovnikowych (Grossulariaceae). In: Anatomia i Ultrastruktura Plodov: 60-82. Kartia Moldoweniaskie. Kishyniev

KRAUS G. 1949. Morphologisch-anatomische Untersuchung der Enwicklungsbedingten Verände-rungen an Achse, Blatt und Fruchtknoten bei einigen Beerenfrüchten. Österr. Bot. Z. 96 : 325-360

NETOLITZKY F. 1926. Anatomie der Angiospermen-Samen. In: Linsbauer K. Hanbuch der Pflanzenanatomie 10. Verlag von Gebrüder Borntraeger.

POHL F. 1923. Zur Kenntnis unserer Beerenfrüchte. Beih. Bot. Cbl. 39: 206-221

RAUH W. 1941. Morphologie der Nutzpflanzen. Quelle \& Meyer. Leipzig

SCHERMANN S. 1967. Magismeret 1,2. Akademiai Kiado. Budapest

SYNGE P.M. (ed.) 1966. Colour chart table of cross references. The Royal Horticultural Society. London

WROŃSKA-PILAREK D. 2001. Seed morphology of the Polish native species of the genus Ribes L. Part 1. General characteristic. Acta Soc. Bot. Pol. 70: 281-289.

\section{MORFOLOGIA NASION KRAJOWYCH GATUNKÓW Z RODZAJU RIBES L. CZĘŚĆ II. CHARAKTERYSTYKA POSZCZEGÓLNYCH GATUNKÓW}

\section{STRESZCZENIE}

W pracy przedstawiono wyniki badań morfologicznych nad nasionami 6 krajowych gatunków z rodzaju Ribes L. (Grossulariaceae). Obserwacje przeprowadzono przy użyciu różnych typów mikroskopów: stereoskopowego, świetlnego oraz skaningowego. Opisy morfologiczne nasion zostały zilustrowane seriami zdjęć spod tych mikroskopów. Do najważniejszych cech diagnostycznych nasion badanych gatunków należą barwa i struktura sarkotesty, wielkość i stopień okrycia nasiona przez arylusy, zarys nasion oraz stosunek ich długości do szerokości. Na podstawie tego kompleksu cech można odróżniać: Ribes uva-crispa L., R. nigrum L. oraz R. alpinum L. Pozostałe gatunki $-R$. petraeum Wulfen, $R$. rubrum L.i $R$. spicatum Robson na podstawie samych nasion są niemożliwe do rozróżnienia. W przypadku nasion pozbawionych zewnętrznych, miẹkiszowych warstw egzotesty (sarkotesta i warstwa miẹkiszowa) możliwe jest jedynie wyodrębnienie nasion $R$. uva-crispa L. i $R$. nigrum L.. Nasiona pozostałych gatunków są wówczas nieodróżnialne. W pracy zamieszczono klucze do oznaczania 6 krajowych gatunków z rodzaju Ribes, według cech morfologicznych owoców i śwież ch nasion oraz według cech ,nasion oczyszczonych".

SŁOWA KLUCZOWE: Grossulariaceae, Ribes, morfologia nasion, morfologia owoców, SEM, LM. 